\title{
Whole-Genome comparative analysis reveals genetic mechanisms of disease resistance and heat tolerance of tropical Bos indicus cattle breeds
}

\begin{tabular}{|c|c|}
\hline Journal: & Genome \\
\hline Manuscript ID & gen-2021-0030.R3 \\
\hline Manuscript Type: & Note \\
\hline $\begin{array}{r}\text { Date Submitted by the } \\
\text { Author: }\end{array}$ & 24-Oct-2021 \\
\hline Complete List of Authors: & $\begin{array}{l}\text { Vijayakumar, Periyasamy; Veterinary College and Research Institute, } \\
\text { TANUVAS, Animal Genetics and Breeding } \\
\text { Singaravadivelan, Arunasalam; Veterinary College and Research } \\
\text { Institute, TANUVAS, Livestock Production Management } \\
\text { Mishra, Anamika; High Security Animal Disease laboratory, } \\
\text { Jagadeesan, Krishnan; University Training and Research Centre, } \\
\text { Pillayarpatty - } 613403 \text {, Animal Genetics and Breeding } \\
\text { Bakyaraj, Sanniyasi; College of Poultry Production and Management, } \\
\text { TANUVAS } \\
\text { Suresh, Ramalingam; Veterinary College and Research Institute, } \\
\text { TANUVAS, Animal Genetics and Breeding; Indian Veterinary Research } \\
\text { Institute, } \\
\text { Sivakumar, Thiagarajan ; Veterinary College and Research Institute, } \\
\text { TANUVAS, Livestock Production Management }\end{array}$ \\
\hline Keyword: & Bos indicus, disease resistance, thermotolerance, SNPs, InDels \\
\hline $\begin{array}{r}\text { Is the invited manuscript for } \\
\text { consideration in a Special } \\
\text { Issue? : }\end{array}$ & Not applicable (regular submission) \\
\hline
\end{tabular}

\section{SCHOLARONE ${ }^{\text {M }}$ Manuscripts}


Whole-Genome comparative analysis reveals genetic mechanisms of disease resistance and heat tolerance of tropical Bos indicus cattle breeds

P. Vijayakumar, A. Singaravadivelan, R. Suresh, and T. Sivakumar. Veterinary College and Research Institute, TANUVAS, Orathanadu-614 625, Thanjavur, Tamil Nadu, India.

11 K. Jagadeesan. Veterinary University Training and Research Centre, Pillaiyarpatti - 613 403, 12 Thanjavur, Tamil Nadu, India.

13 S. Bakyaraj. College of Poultry Production and Management, TANUVAS, Hosur-635 110, 14 Krishnagiri, Tamil Nadu, India.

A. Mishra. ICAR-National Institute of High-Security Animal Diseases, OIE Reference lab for Avian Influenza, Bhopal - 462021, Madhya Pradesh, India

Corresponding author: Periyasamy Vijayakumar (e-mail: nayaganviji@gmail.com). 


\section{Abstract}

28 The Bos indicus cattle breeds have been naturally selected over thousands of years for disease resistance and thermo-tolerance. However, a genetic mechanism of these specific inherited characteristics needs to be discovered. Hence, in this study, the whole-genome comparative analysis of Bos indicus cattle breeds of Kangayam, Tharparkar, Sahiwal, Red Sindhi, and Hariana of the Indian subcontinent was conducted. The genetic variants identification analysis revealed a total of $15,58,51,012$ SNPs and 1,00,62,805 InDels in the mapped reads across all Bos indicus cattle breeds. The functional annotation of 17,252 genes that comprised both, SNPs and InDels, of high functional impact on proteins, has been carried out. The functional annotation results revealed the pathways that were involved in the innate immune response including toll-like receptors, a retinoic acid-inducible gene I like receptors, NOD-like receptors, Jak-STAT signaling pathways, and the non-synonymous variants in the candidate immune genes. Further, we also identified several pathways involved in heat shock response, hair and skin properties, oxidative stress response, osmotic stress response, thermal sweating,

41 feed intake, metabolism, and the non-synonymous variants in the candidate thermo-tolerant genes. These pathways and genes were directly or indirectly contributing to the disease resistance and thermo-tolerance adaptations of Bos indicus cattle breeds.

Keywords: Bos indicus, disease resistance, thermo-tolerance, SNPs, InDels 


\section{Introduction}

The Bos indicus cattle breeds (Zebu cattle) are characterized by the hump at the withers, pendulous skin in the dewlap and navel, draught ability, fertility at the higher temperature, maintenance of production performance in low input system, robustness, adaptability, disease resistance, and thermo-tolerance in tropical climates (Cunningham and Syrstad 1987). Among these characteristics of zebu cattle, thermo-tolerance and disease resistance are being important traits exploited for cross-breeding programs in production commercial dairy and beef cattle production (Cunningham and Syrstad 1987; Madalena et al. 2019; Vijayakumar et al. 2019a). Therefore, the characterization of these two traits in Bos indicus cattle at the genome level seems a strategic plan to design sustainable breed selection programs. Further, the identification of genes and genomic variants likely responsible for these fitness traits in indicine cattle breeds will be useful for the selection of disease resistance and heat tolerance animals in the future (Berry et al. 2011; Singh et al. 2014). This may be considered as one mitigation strategies to handle the current global climate-changing scenario (Escarcha et al. 2018; OseiAmponsah et al. 2019). Thus, tapping the genomic basis of Bos indicus cattle breeds requires a timely and effective approach, especially considering the value and importance of these animal genetic resources. The high intensity of artificial selection was applied to Bos taurus cattle in comparison with Bos indicus cattle to improve economically valuable traits.

The innate immune response plays a crucial role in the disease resistance mechanism against pathogen infection. Because its non-specific immune response is activated at the very initial stages in any pathogens/parasitic infection in the animal body system. The potent innate immune system activation is essential for the development of pathogen-specific adaptive immune responses (Mishra et al. 2017). Further, an in-depth and complete understanding of the cattle's natural anti-infectious immunity is essential for the effective management of cattle 
sequencing technologies has significantly improved our understanding of the cattle immune system (Meade 2015). It should be pointed out that, the complete knowledge of genes, genetic variants, and molecular pathways responsible for disease resistance traits in indicine cattle breeds that originated in the Indian subcontinent are not identified to date (Meade 2015; Vlasova and Saif 2021).

The thermo-tolerance of cattle breeds is the ability of animals to regulate their body temperature by balancing heat gain and heat loss (Sunil et al. 2011; Paula-Lopes et al. 2013). This adaptive mechanism is achieved through changes in gene expression patterns and the activity of biochemical molecules that regulate cellular functions against heat stress (Bernabucci et al., 2010; Sunil et al. 2011; Paula-Lopes et al. 2013). The previous studies identified several genes contributing to thermo-tolerance in different species (reviewed in Belhadj Slimen et al. 2015; Archana PR et al. 2017). In cattle, well-known and widely studied genes related to heat stress are heat shock proteins (HSPs) and higher expression of these HSPs protects the cell against hyperthermia (Qiu et al. 2006; Collier et al. 2008; Gupta et al. 2013). Further, genes involved in antioxidant production, sweat gland development, and sweating, has also been reported to contribute to the thermo-tolerance mechanism in cattle (Wilke et al. 2007; Akers and Denbow 2008).

Further, improving thermo-tolerance capacity among productive cattle breeds through conventional quantitative genetics is difficult because of its negative correlation with the production performance traits (Dikmen et al. 2012; Bernabucci et al. 2014; Carabaño et al. 2014; Nguyen et al. 2016). Hence, understanding the molecular mechanism of thermotolerance processes may provide solutions to select heat-tolerant animals with high production potential (Belhadj Slimen et al. 2015; Min et al. 2017; Carabaño, 2016). However, information on molecular pathways and genes responsible for the thermo-tolerance mechanisms of Bos indicus cattle that originated in the Indian subcontinent is very scarce (Carabaño et al. 2019). 

This study is planned to understand the molecular mechanism and the key genetic variants present in the candidate genes for disease resistance and thermo-tolerance traits in Bos indicus cattle breeds in comparison with temperate Bos taurus cattle. Our study results were highlighting the unique genome response to disease resistance and thermo-tolerance adaptations of Bos indicus breeds of cattle that originated in the Indian subcontinent. Further, the genetic variants identified in this study can be used for the creation of custom-designed SNP genotyping chips, marker-assisted selection, and genomic selection of animals in the future.

\section{Materials and methods}

\section{Whole-genome datasets and read mapping}

113 We used whole-genome data of five zebu cattle breeds that originated in the Indian

114 subcontinent including Kangayam $(n=1)$, Tharparkar $(n=3)$, Sahiwal $(n=2)$, Red Sindhi (n

$115=1)$ and Hariana $(\mathrm{n}=1)$ breeds available at NCBI public database (Accession no. 116 PRJNA496267 and PRJNA493191) (Table 1). The quality control of raw sequencing reads was

117 performed using the FastQC program (Andrews 2010). The Trimmomatic software was used 118 for quality filtering of the short reads (Bolger et al. 2014). The quality reads were mapped into

119 Bos taurus reference genome assembly ARS-UCD1.2 using the Bowtie2 with default 120 parameters (Langmead and Salzberg 2012). The "MarkDuplicates" tool of Picard tools was 121 used to remove potential PCR duplicates from the aligned reads and then the uniquely mapped 122 reads were used for the variant calling step.

Variant calling

124 Freebayes is a Bayesian genetic variant detector that was used with default parameters 125 to find SNPs (single-nucleotide polymorphisms), indels (insertions and deletions), MNPs 126 (multi-nucleotide polymorphisms), and complex events (composite insertion and substitution 
events) in our mapped datasets (Garrison and Marth 2012). After the variant calling step, the

128 'SnpSift filter' tool was used to remove sequencing and alignment artifacts from the SNPs and

129 Indels with the following parameters '(DP >=2)|(QUAL >= 20)' (Cingolani et al. 2012).

130 Further, the freebayes output was filtered to include high-quality variants in the candidate

131 genes, i.e., quality $(\mathrm{QUAL})>1$, presence of supporting reads on both strands $(\mathrm{SAF}>0$ and

132 SAR $>0)$ and both sides of the variant (RPL $>1$ and RPR $>1)$, and high quality per alternate observation (QUAL/AO > 4).

\section{Variation annotation}

SnpEff is a variant annotation and effect prediction tool that was used for functional annotation of identified variants. The identified SNP/InDels were classified as high, moderate, low, and modifier by using the SnpEff tool (Cingolani et al. 2012). All analyses were done on the Galaxy server (https://usegalaxy.org/) (Afgan et al. 2016). Genes comprising of high and moderate impact were used for pathway analysis in the Kyoto Encyclopedia of Genes and

141 Genomes (KEGG) pathway (Kanehisa and Goto 2000) to relate the biological process and 142 pathways associated with disease resistance and thermo-tolerance of zebu cattle breed adaptability in the tropics (Fig. 1). The Cattle Quantitative Trait Locus database (Cattle QTLdb)

144 (https://www.animalgenome.org/cgi-bin/QTLdb/BT/index) contains cattle QTL, candidate genes responsible for 685 traits, and association data curated from 1,049 publications. The

146 candidate genes related to disease resistance and thermo-tolerance were retrieved using 'Search

147 and Analysis Tools' of Cattle QTLdb. In addition, innate immunity related genes were also retrieved from the InnateDB database

149 (http://www.innatedb.com/annotatedGenes.do?type=innatedb). The protein-protein

150 interaction (PPI) networks and gene ontology terms analysis were done in the NetworkAnalyst

151 server to gain the functional roles of retrieved candidate genes from Cattle QTLdb and 
152 InnateDB databases in structuring and mediating the biological processes of disease resistance and thermo-tolerance of zebu cattle breeds (Fig. 2 and 3) (Xia et al. 2014).

\section{Results and discussion}

The Bos indicus cattle breeds are known for their unique genetic features like draught ability, disease resistance, and thermo-tolerance in tropical climates. However, a genetic mechanism of these specific inherited characteristics of Bos indicus cattle needs to be revealed. Through comparisons of tropical Bos indicus cattle breeds genome with temperate Bos taurus genome, the genetic variants, biological processes, and signaling pathways responsible for the adaptations of indicine breeds to tropical environments can be identified. To investigate this; a whole-genome analysis study was carried out using the whole-genome sequence of Indian subcontinent originated indicine cattle breeds (Kangayam, Tharparkar, Sahiwal, Red Sindhi, and Hariana) which was previously published and submitted in the public database repository (Table 1). A total of 15,58,51,012 SNPs and 1,00,62,805 InDels were detected in the mapped reads across all indicine cattle breeds, in which Tharparkar cattle exhibiting the highest number

167 of genetic variants followed by Sahiwal cattle (Table 2). SNP quality was assessed by calculating the transition (Ts) versus transversion (Tv) ratio of all detected SNPs. This Ts/Tv ratio is the indicator of potential sequencing error. Ts/Tv ratio in our study ranges from 2.16 to 2.26 (Table 3), which reflects the good quality of the identified SNPs. The observed Ts/Tv

171 ratios were similar to the previous studies in the cattle genome (Choi et al. 2013, 2014;

172 Daetwyler et al. 2014; Iqbal et al. 2019; Zhang et al. 2019). The identified variants were 173 functionally annotated using SnpEff and the variants were classified into locational (e.g., 174 intergenic, intron, and intragenic) and functional (e.g., stop_gained, start_lost and stop lost) 175 categories (Table 4). Among the total identified variants in this study, the highest variants are 176 found in the intron region (Table 4). 
The identified SNP/InDels were classified as high, moderate, low, and modifier as per

178

179

180

181

182

183

184

185

186

187

188

189

190

191

192

193

194

195

196

197

198

199

200

their functionality of the SnpEff program (Cingolani et al. 2012). The 'high' impact variants have a disruptive impact on the protein that may cause protein truncation, loss of function, or triggering nonsense-mediated decay. The 'moderate' impact variants have a non-disruptive variant that might change protein effectiveness (Cingolani et al. 2012). The functional annotation of high or moderate genetic impact variants may provide a valuable resource for understanding the tropical adaptation and production-related traits of Bos indicus cattle breeds (Iqbal et al. 2019). Hence, such functional impact genetic variants identified in all indicine cattle breeds were combined and analyzed to identify the genetic variants present in the candidate genes, biological process, and signaling pathways responsible for the heat tolerance and disease resistance adaptation of indicine cattle breeds. A total of 17,252 genes that comprised both, an SNP and an INDEL, of high or moderate functional impact on proteins, were identified in all indicine cattle breeds.

\section{Pattern-recognition receptors}

The innate immune system acts as the first line of defense against microbial infection or tissue damage (Akira et al. 2006; Beutler et al. 2006). Furthermore, host innate immunity is very crucial for the induction and regulation of acquired immunity. Germline-encoded pattern recognition receptors (PRRs) are responsible for recognizing microbial species-specific structures, termed pathogen-associated molecular patterns (PAMPs). The well-known PRRs were identified in this study (Fig. 1), including toll-like receptors (TLRs), a retinoic acidinducible gene I (RIG-I)-like receptors (RLRs), and nucleotide oligomerization domain (NOD)-like receptor family pyrin domain containing 3 (NLRP3), which induce the expression of type I interferons (IFNs), pro-inflammatory cytokines, and chemokines (Mishra et al. 2017).

\section{Toll-like receptors}



PAMPs such as lipids, proteins, and nucleic acids (Brubaker et al. 2015). Among the ten TLRs reported in cattle (McGuire et al. 2006), we identified missense variants in TLR3 and TLR4 genes in indicine cattle breeds (Table S1). Cargill and Womack, 2007 reported SNPs and indels for the viral recognition of TLRs in bovine. After PAMP binding into TLRs resulted in the activation of signaling adaptor molecules, including myeloid differentiation factor 88 (MyD88) and TIR domain-containing adaptor inducing interferon (IFN)- $\beta$ (TRIF), which further introducing downstream enzymatic cascades (Brubaker et al. 2015). MyD88 is very essential adaptor molecule in TLR signaling and most TLRs except TLR3, use MyD88 as the adaptor molecule to activate the canonical NF- $\mathrm{BB}$ pathway for the synthesis of proinflammatory cytokines (Kaisho and Akira 2001; West et al. 2006). The MyD88 associates interleukin-1 receptor-associated kinase (IRAK) 1-IRAK4 to form a complex, it will recruit and activate TNFR-associated factor (TRAF) 6 (Deguine and Barton 2014). We observed non-synonymous SNPs in MyD88 and IRAK4 genes (Table S1). Jann et al. 2009 reported that the MyD88 gene

216 is likely candidate genes underlying QTL regions for resistance to pathogens in cattle. MyD88-

217 knockout $(\mathrm{KO})$ mice experiment results indicates the essential role of MyD88 in the LPS activated innate immune signaling (Kawai et al. 1999). TRIF acts as an essential adaptor in the MyD88-independent pathway of TLR3 signaling (Oshiumi et al. 2003). Further, TRIF- knockout mice show impairment in both TLR3- and TLR4-mediated IRF3 activation and the expression of IFN- and IFN-inducible genes (Yamamoto et al. 2002). This non-synonymous variations in the MyD88 and IRAK4 genes may likely play a role in disease resistance traits observed in the indicine cattle. of antiviral type I IFNs and various pro-inflammatory cytokines and chemotactic factors. In 
227 type I IFN production. The upstream kinase complex TBK1/IKK activates the IRF3 transcription factor, which induces type I IFN expression mediated by TLR3/4 ligands (Fitzgerald et al. 2003). Similarly, activation of the IRF7 transcription factor induces type I IFN production through the MyD88-dependent TLR7/9 signaling pathway (Kawai and Akira 2011.). Further, NF- $\kappa B$ transcription factor activation is largely responsible for the production of various proinflammatory cytokines and chemotactic factors after TLR ligand engagement (Table S2). In our study, we find missense variants in IRFs (IRF3/IRF7) and NF- $\kappa B$ transcription factors (Table S1). Among these transcription factors, IRF3 is a likely interesting candidate gene in the context of resistance to viral infections (Pina-Vazquez et al. 2007; Shoemaker et al. 2009; Jann et al. 2009). Similarly, Jann et al. 2009 identified TLR1, MyD88, and IRF3 as the probable candidate genes for the resistance to pathogens in cattle and other livestock species.

\section{Retinoic acid-inducible gene I (RIG-I)-like receptors}

The RIG-I-like receptor (RLR) family is comprising of RIG-I, melanoma differentiation-associated gene 5 (MDA5), and LGP2 (Takeuchi and Akira 2010; Mishra et al. 2017). These cytosolic proteins have two N-terminal caspase recruitment domains (CARDs), a central DEAD-box helicase/ATPase domain, and a C-terminal regulatory domain (Takeuchi

O \& Akira S, 2010). RLRs recognize the genomic RNA of dsRNA viruses and establish the antiviral state of the cell by induction of type I interferon expression (Yoneyama et al. 2004). After dsRNA binding into RIG-I, and consequently, there are conformational changes that expose the CARDs. The CARD domains are ubiquitinated by IFN-inducible E3 ubiquitin ligase, tripartite motif 25 (TRIM25) (Takeuchi and Akira 2010). The CARDs of RIG-I interacting with the N-terminal CARD-containing adaptor mitochondrial antiviral signaling protein (MAVS) (Seth et al. 2005). This modification is required for the activation of RLR signaling. The downstream signaling molecules for the expression of IFN-inducible genes are 
shared between the MAVS and TRIF signaling pathways (Takeuchi and Akira S 2010; Xu et al. 2019). MAVS activates signaling cascades leading to the expression of type I IFN genes via activation of IRF3/7 transcription factors (Goubau et al. 2013; Mishra et al. 2017). Further, MAVS signaling induces activation of NF-B and the production of pro-inflammatory cytokines and chemokines (Goubau et al. 2013; Xu et al. 2019). We observed non-synonymous variants in RIG-I, TRIM25, and MAVS genes (Table S1). Cargill et al. 2006 reported a single SNP in the RIG-1 gene in bovine.

\section{Nucleotide oligomerization domain (NOD)-like receptor}

The NOD-like receptors (NLRs) family consists of a large cytosolic receptor family that responds to bacterial, viral, and fungal infections (Motta et al. 2015). The noninflammasome-forming NOD1 and NOD2 and the inflammasome-forming NALP3, NLRC4, NLRP1, NLRP6, NLRP7, and NLRP12 play vital roles in innate immune responses (Xu et al. 2019). Activation of NOD1 and NOD2 receptor recognize bacteria-derived structures resulted in activation of the canonical NF- $\mathrm{kB}$ and MAPK pathways (Fig. 1), which induce proinflammatory cytokine genes (Chen et al. 2009; Magalhaes et al. 2011). We identified the non-synonymous SNPs in NOD1, and NOD2 genes (Table S1). Pant et al. (2007) identified that a single SNP in the coding region of the NOD2 gene, which was associated with a mastitisrelated trait.

\section{Interferon stimulated genes (ISGs) signaling pathway}

Activation of the various PRRs resulted in the production of IFNs, pro-inflammatory cytokines, and chemokines (Table S2) (Takeuchi and Akira 2010). Three IFN types have been identified, such as type I IFN (IFNA and IFNB), type II (IFNG), and type III (IFNL) (ChelbiAlix MK and Wietzerbin J, 2007). The type I and II IFNs genes bind to IFNAR1/IFNAR2 and IFNGR1/IFNGR2 corresponding receptors of the same cell or neighboring cells, which activate

276 the Jak-STAT signaling (Fig. 1). Activation of Jak-STAT signaling leads to the 
phosphorylation and nuclear translocation of IFN-stimulated gene factor 3 (ISGF3), a complex

278

279

280

281

282

283

284 comprising of signal transducer and activator of transcription 1 (STAT1), STAT2, and IRF9. ISGF3 induces the expression of IFN-inducible antiviral genes such as MX1, OASL, IFITM5, IFITM3, IFIT5, PKR, TGFB1, GBP 1, GBP 7, and RSAD2 among others (Mishra et al. 2017). We identified non-synonymous variants in IFNAG, IFNB, OASL, IFITM5, IFITM3, IFIH1, and PKR genes in the zebu cattle genome (Table S1). Polymorphisms in some of these genes may likely be associated with resistance to viral infections in mice and humans have been reported (Sadler and Williams 2008). However, very limited information is only available for bovine. The type I interferons of bovine are polymorphic and associated with BHV-1 infections (Ryan et al. 1993; Muller-Doblies et al. 2002). The MX genes were expressed in response to BHV-1, BRV, and single-stranded RNA paramyxoviridae virus infection in cattle (Nakatsu et al. 2004; LeRoy et al. 2005). The OASL protein degrades the viral RNA in the cytosol and polymorphisms in the OASL gene have been associated with flavivirus resistance in mice (Perelygin et al. 2005, 2006a). PKR protein effectively reducing viral replication by decreases viral protein synthesis (Chinsangaram et al. 2001, Gil et al. 2006). Previous literature reported the evidence for polymorphisms in some of these ISGs in cattle (Ryan and Womack 1993; Nakatsu et al. 2004), however, no associations with disease resistance have been defined in cattle (Glass et al. 2010). Collectively, our results indicate that activation of various innate immune pathways and the presence of nonsynonymous variations in TLRs, RLRs, NLRs, signaling adaptor molecules, transcription factors, and IFN-inducible genes may likely enhance disease resistance immune response against infectious diseases in indicine cattle breeds.

\section{Molecular mechanism of heat shock protein (HSP) synthesis and function related to}

\section{thermo-tolerance}

Heat shock proteins (HSPs) genes are very extensively studied genes that are associated with thermo-tolerance in cattle (Archana et al. 2017). The expression of the HSPs is mainly 
controlled at the transcription level by a family of heat shock transcription factors (HSF) (Morimoto 1993). Under heat stress or hyperthermia conditions, the HSF1 dissociate from HSP to form trimers of the HSF1 complex (Pirkkala et al. 2001). In the nucleus, the homotrimeric HSF1 binds with the heat shock elements (HSE) present in the promoter region of the HSPs genes resulted in enhanced HSP gene transcription (Guertin and Lis 2010). The following heat shock factors such as HSF1, HSF2, HSF2BP, HSF4, and HSF5 were expressed in cattle. Among these HSFs, HSF1 is the major regulator of HSP70 transcription in eukaryotes (Trinklein et al. 2004). Further, HSF1 has been associated with carbohydrate metabolism, transport, cytoskeleton, and ubiquitination during heat stress conditions in cattle (Page et al. 2006).

HSP increases the thermo-tolerance of animals through their functioning as molecular chaperones (Gupta et al. 2013; Belhadj Slimen et al. 2015). The HSP maintains protein homeostasis through facilitating the assembly and translocation of newly synthesized proteins, prevention of inappropriate protein aggregation, and repairing and refolding of aggregated proteins during cellular response to heat stress (Table S3) (Hightower 1991; Moseley 1997;

317 Feder and Hofmann, 1999). In the cattle genome, 26 genes encoding molecular chaperones that may contribute heat tolerance to zebu cattle have been identified. These included members of HSP70 family (HSPA4L, HSPA8, HSPA1A, HSPA2, HSPA1L, HSPA6, HSPA4, HSPA5, HSPA13, and HSPA9), HSP60 (HSPD1), HSP90 (HSP90AA1, HSP90AB1, HSP90B1), HSP10 (HSPE1), HSP110 (HSPH1) and HSP40 (DNAJA1, DNAJB1, DNAJC1, DNAJC8, DNAJC3, DNAJC17, etc.). We identified non-synonymous variants in HSF1, HSP70 family (HSPA4L, HSPA1A, HSPA1L, HSPA6, HSPA4, HSPA5, HSPA13, and HSPA9) and HSP90 family (HSP90B1) genes in indicine cattle breeds (Table S1). 
et al. 2015). HSP70 family in bovines, HSP70-1 (HSPA1) and HSP70-2 (HSPA1L) proteins are highly conserved, and most abundant proteins (Hansen 2004; Basiricò et al. 2011; SalcesOrtiz et al. 2013; Kishore et al. 2014). The upregulation of HSP70, HSP90, HSP32, HSP40, HSP60, and HSP110 proteins were observed and playing a crucial role in thermal adaptation in cattle, buffalo, broilers, sheep, and goats (Mazzi et al. 2003; Yu et al. 2008; Mishra et al. 2011; Gupta et al. 2013; Banerjee et al. 2014; Mehla et al. 2014; Pawar et al. 2014; Shaji et al. 2015).

The overexpression of HSP70 in the intestine significantly improves digestion and absorption function in the broiler during heat stress (Table S3) (Hao et al. 2012). Further, the ATPase activity of HSP70 is regulated by HSP40 through interacting with the J domain of the HSP70 proteins (De Maio 1999). HSP90 proteins assist in protein folding and protein stabilization (Table S3) (Panaretou et al. 2002). The HSP protein in extracellular fluids is involved in immuno-modulation through the signaling of innate and acquired immune pathways (Table S3) (Mishra et al. 2011). Further, the HSP70 along with HSP27 and HSP90 proteins is involved in the inhibiting of apoptosis in mammalian cells (Table S1) (Garrido et al. 2001). The previous study suggesting the role of HSP70 in the induction of antitumor immunity through the production of chemokines from tumor cells via the TLR4 signaling pathway in mice (Chen et al. 2009). Chen et al. (2009) reported that HSP70 (including HSP70i and HSC70) is the major HSP responsible for the autocrine induction of chemokines from tumor cells. In Bos indicus breeds, the reproductive performance difference observed in these breeds has been associated with polymorphism in HSP70 (Table S3) (Rosenkrans et al. 2010;

348 Cushman 2013). Variations in the HSP70 family genes and other HSP genes are a potential strategy adopted by different cattle breeds to different seasons. Hence, the HSP genes serving as the suitable genetic markers for the selection of thermal tolerance cattle (Kumar et al. 2015).

351 The previous studies reported that polymorphisms in HSP genes associated with heat-tolerant 
such as HSP90AB1, in Thai native cattle, the 5'-UTR region of HSP70 in Holstein cows (Basirico et al. 2011), the HSF1 gene, and HSP70A1A gene in Chinese Holstein cattle (Li et al. 2011; Deb et al. 2014). Our results were in close agreement with the previously published studies. In summary, our functional annotation results and non-synonymous variations in HSP genes would explain part of tropical cattle adaptability of zebu cattle breeds. an influence on hair morphology and thermo-tolerance in the taurine Senepol cattle (Fig. 1) (Littlejohn et al. 2014; Vijayakumar et al. 2019b). Further, the increased plasma prolactin concentration is to be connected with the altered metabolic state of heat-stressed animals (Sunil et al. 2011; Gupta et al. 2013). In indicine cattle breeds, we identified missense variants in the PRLH gene (Table S1). These results together suggest that the PRLH mutation possibly confer a selective advantage to the thermo-tolerance mechanism of indicine cattle. Heat stress rises the production of a large number of free radicals and reactive oxygen species (ROS) which cause cytotoxicity (Sunil et al. 2011; Belhadj Slimen et al. 2015). In this condition, the host activates the oxidative stress response through increased activities of antioxidant enzymes like SOD1, GPX7, GSTM2, GSTM4, SLC23A1, and SLC23A1 to destroy free radicals and maintain hemostasis in the body (Table S3) (Belhadj Slimen et al. 2015; Davidson et al. 1996; Sunil et al. 2011; Gupta et al. 2013; Chen et al. 2016). Kim et al. 2014 suggested that variations in antioxidant enzymes like the SOD1 gene possibly play an important role in heat tolerance traits observed in African cattle. Similarly, we observed missense variants in the SOD1 gene in indicine cattle breeds (Table S1).

A genetic variation identified in the BHMT2, PLCB4, CFTR, ITPR2, SLC9A4, and MC5R genes may likely play important role in the thermotolerant mechanism of zebu cattle (Table S1). The BHMT2 gene is involved in the regulation of homocysteine metabolism with beneficial effects in heat-stressed animals through its activity against osmotic stress and 
protection from protein denaturation (Cottrell et al. 2015; Del Vesco et al. 2015). The PLCB1

378

379

380

381

382

383

384

385

386

387

388

389

390

391

392

393

394

395

396

397

398

399

400 and PLCB4 are enzymes involved in the energy metabolism process and positively selected in bovines in response to adaptation to dry arid environments (Kim et al. 2015; Li et al. 2019). The zebu cattle lose incredible amounts of heat through the sweating mechanism (Akers and Denbow 2008). Taye et al. (2017) reported that the genes such as ITPR2, ITPRIP, CFTR, SCNN1D, and SLC9A4 were involved in the thermal sweating of African cattle. Further, Wnt signaling and calcium signaling pathways likely responsible for thermal sweating were identified in the KEGG pathways analysis (Fig. 1) (Cui et al. 2014; Cui and Schlessinger 2015; Taye et al. 2017). MC5R regulates exocrine glands and controls the secretion of sebum (Zhang et al. 2006). Sebum lubricates skin and hair with the function of hydrophobic protection against overwetting and for thermal insulation in cattle (Zouboulis 2004; Akers and Denbow 2008). Mammalian skin hair and coat color provide physical protection and thermoregulation functions in cattle (Jian et al. 2014). Cattle have a thermo-tolerant mechanism through the enhanced conductive and convective heat loss and reduce the absorption of solar radiation (Hansen 2004; Lenis Sanin et al. 2016). Previous studies reported the non-synonymous variation in genes such as SLC45A2, MLPH, RAB17, and ATRN involved in the regulation of melanogenesis processes is very important for the differences in cattle breeds in pigmentary traits (Sturm 2009). Similarly, we identified non-synonymous variations in the above said gene list in the zebu cattle genome (Table S1). In summary, we identified various non-synonymous variations in the majority of candidate genes and the biological processes may likely be related to thermo-tolerance in indicine cattle breeds. Our results were in close agreement with the previous studies involved in different cattle breeds (Bolormaa et al. 2011; Fortes et al. 2012; Lee et al. 2013; Gurgul et al. 2016; Taye et al. 2017a; 2017b; Dias et al. 2017; Nayeri et al. 2017; Edea et al. 2018; Alshawi et al. 2019). However, the limitation of the present study is 
there is a possibility of obtaining false-positive results as common in this kind of study. Hence, validation with GWAS, candidate gene approach, and gene expression analysis are suggested.

\section{Conclusion}

This study provides a comprehensive overview of the molecular mechanism of disease resistance and thermo-tolerance of Indian subcontinent originated cattle breeds. So far, the available literature information on disease resistance and thermo-tolerance of Bos indicus cattle breeds mostly belong to African zebu cattle breeds. Only very few studies were available for Indian subcontinent originated cattle breeds. Hence, our study results may likely provide the molecular pathways putatively responsible for these traits of the cattle breeds that originated in

411 the Indian subcontinent. Further, this molecular mechanism of specific climate-resilient adaptive animals to Indian subcontinent tropical environments is currently required to combat

413 climate change-related adverse effects and to sustain livestock production systems in Indian 414 subcontinent countries. The identified genetic variants provide a useful resource for further 415 studies to phenotypically differentiate Bos taurus and Bos indicus cattle breeds.

\section{Competing Interests}

418 The authors have declared that no competing interests exist.

\section{Funding}

420 The authors declare no specific funding for this work.

\section{Data Availability}

422 The datasets were used for this analysis are from previously submitted datasets in NCBI which 423 have been cited.

\section{Acknowledgments}

425 The contributions of the whole genome datasets in the public domain are highly acknowledged. 


\section{References}

427

428

429

430

431

432

433

434

435

436

437

438

439

440

441

442

443

444

445

446

447

448

449

Afgan E. Baker D. van den Beek M. Blankenberg D. Bouvier D. Čech M. Chilton J. Clements D. Coraor N. Eberhard C. et al. 2016. The Galaxy platform for accessible, reproducible and collaborative biomedical analyses: 2016 update. Nucleic Acids Res. 44 (W1): W3W10.

Akers, R.M., and Denbow, D.M. 2008. Anatomy and Physiology of Domestic Animals. American Veterinary Medical Association, Blackwell Publishing, Ames, Iowa.

Akira, S., Uematsu, S., and Takeuchi, O. 2006. Pathogen recognition and innate immunity. Cell, 124 (4):783-801. https://doi.org/10.1016/j.cell.2006.02.015.

Alfonzo, E.P.M, da Silva, M.V.G.B., dos Santos, D.D., Stumpf, M.T., Dalcin, V.C., Kolling, G., et al. 2016. Relationship between physical attributes and heat stress in dairy cattle from different genetic groups. International Journal of Biometeorology, 60(2):245-253.

Alshawi, A.F., Essa, A., Al-Bayatti, S., and Hanotte, O.H. 2019. Genome analysis reveals genetic admixture and signature of selection for productivity and environmental traits in Iraqi cattle. Frontiers in Genetics, 10:609.

Andrews, S. 2010. FastQC: a quality control tool for high throughput sequence data. Available online at: http://www.bioinformatics.babraham.ac.uk/projects/ fastqc.

Archana, P.R., Aleena, J., Pragna, P, et al. 2017. Role of heat shock proteins in livestock adaptation to heat stress. J. Dairy Vet. Anim. Res. 5(1):13-19. DOI: 10.15406/jdvar.2017.05.00127

Banerjee, D., Upadhyay, R.C., Chaudhary, U.B., et al. 2014. Seasonal variation in expression pattern of genes under HSP70: Seasonal variation in expression pattern of genes under HSP70 family in heat and cold-adapted goats (Capra hircus). Cell Stress Chaperones, 19(3):401-408. 
450 Basirico, L., Morera, P., Primi, V., et al. 2011. Cellular thermo-tolerance is associated with 451 heat shock protein 70.1 genetic polymorphisms in Holstein lactating cows. Cell Stress Chaperone, 16(4):441-8. doi: 10.1007/s12192-011-0257-7.

Basiricò, L., Morera, P., Primi, V., Lacetera, N., Nardone, A., and Bernabucci, U. 2011. Cellular thermo-tolerance is associated with heat shock protein 70.1 genetic polymorphisms in Holstein lactating cows. Cell Stress Chaperones, 16(4):441-8. doi: 10.1007/s12192-011-0257-7.

Belhadj Slimen, I., Najar, T., Ghram, A., and Abdrrabba, M. 2015. Heat stress effects on

Belhadj Slimen, I., Najar, T., Ghram, A., and Abdrrabba, M. 2015. Heat stress effects on 461 livestock: molecular, cellular and metabolic aspects, a review. Journal of Animal Physiology and Animal Nutrition, 100(3):401-12. doi: 10.1111/jpn.12379.

Bernabucci, U., Biffani, S., Buggiotti, L., Vitali, A., Lacetera, N., and Nardone, A. 2014. The

Bernabucci, U., Lacetera, N., Baumgard, L. H., Rhoads, R. P., Ronchi, B., and Nardone, A. 2010. Metabolic and hormonal acclimation to heat stress in domesticated ruminants. Animal, 4 (7):1167-1183. doi:10.1017/S175173111000090X.

Beutler, B., Jiang, Z., Georgel, P., Crozat, K., Croker, B., Rutschmann, S., Du, X., and Hoebe, K. 2006. Genetic analysis of host resistance: Toll-like receptor signaling and immunity at large. Annu. Rev. Immunol. 24:353-89. 
Bolger, A. M., Lohse, M., \& Usadel, B. (2014). Trimmomatic: a flexible trimmer for Illumina sequence data. Bioinformatics, 30(15):2114-20.

Bolormaa S., Hayes B., Savin K., Hawken R., Barendse W., Arthur P., Herd R. \& Goddard M. (2011) Genome-wide association studies for feedlot and growth traits in cattle. Journal of Animal Science 89, 1684-97.

Brubaker. S.W., Bonham, K.S., Zanoni, I., and Kagan, J.C. 2015. Innate immune pattern recognition: a cell biological perspective. Annu. Rev. Immunol. 33: 257-290. doi:10.1146/ annurev-immunol-032414-112240.

Carabaño, M.J. 2016. The challenge of genetic selection for heat tolerance: the dairy cattle example. Adv. Anim. Biosci. 7(2):218-222. doi:10.1017/S2040470016000169.

Carabaño, M.J., Bachagha, K., Ramón, M., and Díaz, C. 2014. Modeling heat stress effect on Holstein cows under hot and dry conditions: selection tools. J. Dairy Sci. 97(12):7889904. doi: $10.3168 /$ jds.2014-8023.

Carabaño, M.J., Ramón, M., Menéndez-Buxadera, A., Molina, A., and Díaz, C. 2019. Selecting for heat tolerance. Anim. Front. 9(1):62-68. doi:10.1093/af/vfy033.

Cargill, E.J., and Womack, J.E. 2007. Detection of polymorphisms in bovine toll-like receptors 3, 7, 8, and 9. Genomics, 89(6):745-755.

Cargill, E.J., Paetzold, L. and Womack, J.E. 2006. Radiation hybrid mapping and comparative sequence analysis of bovine RIG-I and MAVS genes. DNA Sequence, 17(4):314-318.

Chelbi-Alix, M.K., and Wietzerbin, J. 2007. Interferon, a growing cytokine family: 50 sources of interferon research. Biochimie. 89(6-7):713-718.

Chen, G., Shaw, M.H., Kim, Y.G., and Nunez, G. 2009. NOD-like receptors: role in innate immunity and inflammatory disease. Annu. Rev. Pathol. 4:365-98.

Chen, T., Guo, J., Han, C., Yang, M., Cao, X. 2009. Heat shock protein 70, released from heatstressed tumor cells, initiates antitumor immunity by inducing tumor cell chemokine 
production and activating dendritic cells via TLR4 pathway. J. Immunol. 182(3):1449-1459.

501

Chen, T., Han, G.J., Chaofeng., et al. 2009. Heat shock protein 70, released from heat-stressed tumor cells, initiates antitumor immunity by inducing tumor cell chemokine production and activating dendritic cells via TLR4 pathway. J Immunol. 182(3):1449-59. doi: 10.4049/jimmunol.182.3.1449.

Chen, Y.I., Wei, P.C, Hsu, J.L., Su, F.Y., and Lee, W.H. 2016. NPGPx (GPx7): a novel oxidative stress sensor/ transmitter with multiple roles in redox homeostasis. American Journal of Translational Research, 8(4):1626-40. eCollection 2016.

Chinsangaram, J., Koster, M. and Grubman, M.J. (2001) Inhibition of L-deleted foot andmouth disease virus replication by alpha/beta interferon involves double stranded RNA-

Choi, J.W., Liao, X., Park, S., Jeon, H.J., Chung, W.H., Stothard, P., et al. 2013. Massively parallel sequencing of Chikso (Korean brindle cattle) to discover genome-wide SNPs and InDels. Mol. Cells. 36(3):203-211.

Choi, J.W., Liao, X., Stothard, P., Chung, W.H., Jeon, H.J., Miller, S.P., et al. 2014. Wholegenome analyses of Korean Native and Holstein cattle breeds by massively parallel

517 Cingolani, P., Patel, V. M., Coon, M., Nguyen, T., Land, S. J., Ruden, D. M., and Lu, X. 2012. Using Drosophila melanogaster as a Model for Genotoxic Chemical Mutational Studies with a New Program, SnpSift. Frontiers in Genetics, 3:35. doi: 10.3389/fgene.2012.00035.

Cingolani, P., Platts, A., Wang le, L., Coon, M., Nguyen, T., Wang, L., Land, S.J., Lu, X., and Ruden, D.M. 2012. A program for annotating and predicting the effects of single nucleotide polymorphisms, SnpEff: SNPs in the genome of Drosophila melanogaster strain w1118; iso-2; iso-3. Fly (Austin), 6(2):80-92. 
524 Collier, R., Collier, J., Rhoads, R., and Baumgard, L. 2008. Invited review: genes involved in the bovine heat stress response. Journal of Dairy Science, 91(2): 445-454.

Cottrell, J., Liu, F., Hung, A., DiGiacomo, K., Chauhan, S., Leury, B., et al. 2015. Nutritional strategies to alleviate heat stress in pigs. Animal Production Science, 55(12) 1391-1402 https://doi.org/10.1071/AN15255.

Cui, C.Y., and Schlessinger, D. 2015. Eccrine sweat gland development and sweat secretion. Experimental Dermatology, 24(9):644-50. doi: 10.1111/exd.12773.

Cui, C.Y., Yin, M., Sima, J., Childress, V., Michel, M., Piao, Y., and Schlessinger, D. 2014. Involvement of Wnt, Eda and Shh at defined stages of sweat gland development. Development, 141(19):3752-60. doi: 10.1242/dev.109231.

Cunningham, E.P., and Syrstad, O.1987. Crossbreeding Bos indicus and Bos taurus for milk production in the tropics. FAO Anim. Prod.Health Paper No. 68, Rome, Italy.

Cushman, R.A. 2013. The current status of heat shock in early embryonic survival and reproductive efficiency. J. Anim. Sci. 91(3):1141-1142.

Daetwyler, H.D., Capitan, A., Pausch, H., Stothard, P., Van Binsbergen, R., Brøndum, R.F., et al. 2014. Whole genome sequencing of 234 bulls facilitates mapping of monogenic and complex traits in cattle. Nature Genetics, 46(8):858-65.

541 Davidson, J.F., Whyte, B., Bissinger, P.H., and Schiestl, R.H. 1996. Oxidative stress is involved in heat-induced cell death in Saccharomyces cerevisiae. Proceedings of the National Academy of Sciences, 93(10):5116-21. doi: 10.1073/pnas.93.10.5116.

De Maio, A. 1999. Heat shock proteins: facts, thoughts, and dreams. Shock, 11(1):1-12. doi: 10.1097/00024382-199901000-00001.

Deb, R., Sajjanar, B., Singh, U., Kumar, S., Singh, R., Sengar, G., and Sharma, A. 2014. Effect of heat stress on the expression profile of Hsp90 among Sahiwal (Bos indicus) and 
Frieswal (Bos indicus $\times$ Bos taurus) breed of cattle. Gene. 536(2):435-40. doi: 10.1016/j.gene.2013.11.086.

Deguine, J., and Barton, G.M. 2014. MyD88: a central player in innate immune signaling. F1000Prime Rep. 6: 97. doi:10.12703/P6-97.

Del Vesco, A.P., Gasparino, E., de Oliveira, G.D., Zancanela, V., Soares, M.A.M., de Oliveira Neto, A.R. 2015. Effects of methionine supplementation on the expression of oxidative stress-related genes in acute heat stressexposed broilers. British Journal of Nutrition, 113 (4): 549-559.

Dias M., Canovas, A., Mantilla-Rojas, C., Riley, D., Luna-Nevarez, P., Coleman, S., Speidel, S., Enns, R., Islas-Trejo, A., and Medrano, J. 2017. SNP detection using RNA-sequences of candidate genes associated with puberty in cattle. Genetics and Molecular Research,

Dikmen, S., Cole, J., Null, D., and Hansen, P. 2012. Heritability of rectal temperature and genetic correlations with production and reproduction traits in dairy cattle. Journal of Dairy

Edea, Z., Dadi, H., Dessie, T., Uzzaman, M., Rothschild, M., Kim, E.S., Sonstegard, T., and Kim, K.S. 2018. Genome-wide scan reveals divergent selection among taurine and zebu cattle populations from different regions. Animal Genetics, 49(6):550-63.

Escarcha, J., Lassa, J., and Zander, K. 2018. Livestock Under Climate Change: A Systematic

Feder, M.E., and Hofmann, G.E. 1999. Heat shock proteins, molecular chaperons, and the stress response: evolutionary and ecological physiology. Annu. Rev. Physiol. 6:243e82.

Feder, M.E., and Hofmann, G.E. 1999. Heat shock proteins, molecular chaperones, and the stress response: Evolutionary and ecological physiology. Ann. Rev. Physiol. 61:243-282. 
572 Ferluga, J., Yasmin, H., Al-Ahdal, M.N., Bhakta, S., and Kishore, U. 2020. Natural and Trained Innate Immunity Against Mycobacterium Tuberculosis. Immunobiology, 225(3):151951. doi: 10.1016/j.imbio.2020.151951.

Fitzgerald, K.A., McWhirter, S.M., Faia, K.L., Rowe, DC, et al. 2003. IKKepsilon and TBK1 are essential components of the IRF3 signaling pathway. Nat. Immunol. 4(5): 491- 496. doi:10.1038/ni921.

Fortes, M.R.S., Lehnert, S.A., Bolormaa, S., Reich, C., Fordyce, G., Corbet, N.J., Whan, V., Hawken, R.J., and Reverter, A. 2012. Finding genes for economically important traits: Brahman cattle puberty. Animal Production Science, 52(3):143-50.

Garrido, C., Gurbuxani, S., Ravagnan, L., and Kroemer, G. 2001. Heat shock proteins: Endogenous modulators of apoptotic cell death. Biochem. Biophys. Res. Commun. 286(3):433-442.

Garrison, E., and Marth, G. 2012. Haplotype-based variant detection from short-read sequencing. arXiv preprint arXiv:1207.3907 [q-bio.GN].

Gil, L.H.V.G., van Olphen, A.L., Mittal, S.K. and Donis, R.O. 2006. Modulation of PKR activity in cells infected by bovine viral diarrhea virus. Virus Research, 116(1-2):69-77.

Glass E.J., Baxter, R., Leach, R., and Taylor, G. 2010. Bovine Viral Diseases: The Role of Host Genetics. Bishop, S.C., Axford, R.F.E., Nicholas, F.W., and Owen, J.B. 2010. Breeding for Disease Resistance in Farm Animals: CABI.

591 Goubau, D., Deddouche, S., and Reis e Sousa, C. 2013. Cytosolic sensing of 592 viruses. Immunity, 38 (5):855-69.

593 Guertin, M.J., and Lis, J.T. 2010. Chromatin landscape dictates HSF binding to target DNA elements. PLOS Genet. 6 (9): e1001114. 
595 Gupta, M., Kumar, S., Dangi, S., and Jangir, B.L. 2013. Physiological, biochemical and 596 molecular responses to thermal stress in goats. International Journal of Livestock $597 \quad$ Research, 3 (2):27-38.

598 Gupta., M., Kumar, S., Dangi, S., Jangir, B.L. 2013. Physiological, biochemical and molecular responses to thermal stress in goats. International Journal of Livestock Research, 3(2):27600 38.

601

Gurgul, A., Szmatoła, T., Ropka-Molik, K., Jasielczuk, I., Pawlina, K., Semik, E., and Bugno602 Poniewierska, M. 2016. Identification of genome-wide selection signatures in the Limousin beef cattle breed. Journal of Animal Breeding \& Genetics, 133(4):264-76.

Hansen, P. 2004. Physiological and cellular adaptations of zebu cattle to thermal stress. Anim. Reprod. Sci. 82-83:349-60. doi: 10.1016/j.anireprosci.2004.04.011.

Hansen, P. 2004. Physiological and cellular adaptations of zebu cattle to thermal stress. Animal Reproduction Science, 82-83:349-60

Hao, Y., Gu, X.H., and Wang, X.L. 2012. Overexpression of heat shock protein 70 and its relationship to intestine under acute HS in broilers: 1. Intestinal structure and digestive function. Poult Sci. 91(4):781-789.

Hightower, L.E. 1991. Heat shock, stress proteins, chaperones, and proteotoxicity. Cell, 66(2):191-7. doi: 10.1016/0092-8674(91)90611-2.

613 Hue, N.T., Tran, H.T., Phan T, et al. 2013. Hsp90 and reactive oxygen species regulate thermo614 tolerance of rice seedlings via induction of heat shock factor A2 (OsHSFA2) and galactinol synthase 1(OsGolS1). Agric Sci. 4(3):154-164.

616 Iqbal, N., Liu, X., Yang, T., Huang, Z., Hanif, Q., Asif, M., Khan, Q.M., Mansoor, S. 2019. 617 Genomic variants identified from whole-genome resequencing of indicine cattle breeds 618 from Pakistan. PLoS ONE, 14(4): e0215065. 
619 Jann, O.C., King, A., Corrales, N.L., Anderson, S., Jensen, K., Ait-ali, T., Tang, H., Wu, C., 620 Archibald, A.L., Cockett, N.E., and Glass, E.J. 2009. Comparative genomics of Toll like receptor signalling in five species. BMC Genomics, 10:216.

622

623

624

625

626

627

628

629

630

631

632

633

634

635

636

637

638

639

640

641

642

643

Jian, W., Duangjinda, M., Vajrabukka, C., and Katawatin, S. 2014. Differences of skin morphology in Bos indicus, Bos taurus, and their crossbreds. International Journal of Biometeorology, 58 (6):1087-1094.

Kaisho, T., and Akira, S. 2001. Toll-like receptors and their signaling mechanism in innate immunity. Acta Odontologica Scandinavica. 59(3):124-130. DOI: $10.1080 / 000163501750266701$

Kanehisa, M., and Goto, S. 2000. KEGG: Kyoto Encyclopedia of Genes and Genomes. Nucleic Acids Res. 28(1):27-30.

Kawai, T., Adachi, O., Ogawa, T., Takeda, K., and Akira, S. 1999. Unresponsiveness of MyD88- deficient mice to endotoxin. Immunity, 11(1): 115-122. doi:10.1016/S10747613(00)80086-2.

Kawai, T., and Akira, S. 2011. Toll-like receptors and their crosstalk with other innate receptors in infection and immunity. Immunity, 34 (5): 637- 650. doi: 10.1016/j.immuni.2011.05. 006.

Kim, E., Elbeltagy, A., Aboul-Naga, A., Rischkowsky, B., Sayre, B., Mwacharo, J, et al. 2015. Multiple genomic signatures of selection in goats and sheep indigenous to a hot arid environment. Heredity, 116(3):255-64. doi: 10.1038/hdy.2015.94.

Kim, J., Hanotte, O., Mwai, O.A., Dessie, T., Bashir, S., Diallo, B., et al. 2017. The genome landscape of indigenous African cattle. Genome Biology, 18 (1):34 DOI 10.1186/s13059017-1153-y.

Kishore, A., Sodhi, M., Kumari, P., Mohanty, A.K., Sadana, D.K., Kapila, N., Khate, K., Shandilya, U., Kataria, R.S., and Mukesh, M. 2014. Peripheral blood mononuclear cells: 
644

645

646

647

648

649

650

651

652

653

654

655

656

657

658

659

660

661

662

663

664

665

666

667

a potential cellular system to understand differential heat shock response across native cattle (Bos indicus), exotic cattle (Bos taurus), and riverine buffaloes (Bubalus bubalis) of India. Cell Stress Chaperones, 19(5):613-21.

Kumar, A., Ashraf, S., Goud, T.S., Grewal, A., Singh, S.V., Yadav, B.R., and Upadhyay, R.C. 2015. Expression profiling of major heat shock protein genes during different seasons in cattle (Bos indicus) and buffalo (Bubalus bubalis) under tropical climatic condition. J. Therm. Biol. 51:55-64. doi: 10.1016/j.jtherbio.2015.03.006.

Langmead, B., and Salzberg, S. L. 2012. Fast gapped-read alignment with Bowtie 2. Nature Methods, 9(4):357-9. doi: 10.1038/nmeth.1923.

Lee, T., Cho, S., Seo, K.S., Chang, J., Kim, H., and Yoon, D. 2013. Genetic variants and signatures of selective sweep of Hanwoo population (Korean native cattle). BMB Reports, 46(7):346-51.

Lenis Sanin, Y., Zuluaga Cabrera, A.M., and Tarazona Morales, A.M. 2016. Adaptive responses to thermal stress in mammals. Revista de Medicina Veterinaria 31:121-135.

LeRoy, M., Baise, E., Pire, G., Gerardin, J. and Desmecht, D. 2005. Resistance of paramyxoviridae to type I interferoninduced Bos taurus Mx1 dynamin. Journal of Interferon and Cytokine Research, 25(4): 192-201.

Li, Q., Han, J., Du, F., Ju, Z., Huang, J., Wang, J., Li, R., Wang, C., and Zhong, J. 2011. Novel SNPs in HSP70A1A gene and the association of polymorphisms with thermo tolerance traits and tissue specific expression in Chinese Holstein cattle. Molecular Biology Reports. 38(4):2657-63. doi: 10.1007/s11033-010-0407-5.

Li, R., Li, C., Chen, H., Li, R., Chong, Q., Xiao, H., and Chen, S. 2020. Genome-wide scan of selection signatures in Dehong humped cattle for heat tolerance and disease resistance. Anim Genet. 51(2):292-299. doi: 10.1111/age.12896. 
668 Littlejohn, M.D., Henty, K.M., Tiplady, K., Johnson, T., Harland, C., Lopdell, T., et al. 2014. 669 Functionally reciprocal mutations of the prolactin signalling pathway define hairy and $670 \quad$ slick cattle. Nat Commun. 5:5861. doi: 10.1038/ncomms6861.

671

672

673

674

675

676

677

678

679

680

681

682

683

684

685

686

687

688

689

690

691

Madalena, F.E., Toledo-Alvarado, H., and Cala-Moreno, N. 2019. Animals That Produce Dairy Foods: Bos indicus Breeds and Bos indicus $\times$ Bos taurus Crosses. In Reference Module in Food Science; Elsevier: Amsterdam, The Netherlands.

Magalhaes, J.G., Sorbara, M.T., Girardin, S.E., and Philpott, D.J. 2011. What is new with Nods? Curr. Opin. Immunol. 23:29-34.

Mazzi, C.M., Ferro, J.A., Ferro, M.I.T., Savino, V.J.M., Coelho, A.A.D., and Macari, M. 2003. Polymorphism analysis of the hsp70 stress gene in Broiler chickens (Gallus gallus) of different breeds. Genet. Mol. Biol. 26(3):275-281.

McGuire, K., Jones, M., Werling, D., Williams, J.L., Glass, E.J. and Jann, O. 2006. Radiation hybrid mapping of all 10 characterized bovine Toll-like receptors. Animal Genetics. 37(1):47-50. doi: 10.1111/j.1365-2052.2005.01364. x.

Meade, K.G. 2015. Advances in Bovine Immunology - New Tools and New Insights to Tackle Old Foes. Front Immunol. 6:71. doi: 10.3389/fimmu.2015.00071

Mehla, K., Magotra, A., Choudhary, J., et al. 2014. Genome-wide analysis of the heat stress response in Zebu (Sahiwal) cattle. Gene, 533(2):500-507.

Min, L., Zhao, S., Tian, H., Zhou, X., Zhang, Y., Li, S., Yang, H., Zheng, N., and Wang, J. 2017. Metabolic responses and "omics" technologies for elucidating the effects of heat stress in dairy cows. Int. J. Biometeorol. 61(6):1149-1158. doi: 10.1007/s00484-016-1283$\mathrm{Z}$.

Mishra, A., Hooda, O.K., Singh, G., Meur, S.K. 2011. Influence of induced HS on HSP70 in buffalo lymphocytes. J. Anim. Physiol. Anim. Nutr. 95(4):540-544. 
692 Mishra, A., Vijayakumar, P., and Raut, A.A. 2017. Emerging avian influenza infections: 693 Current understanding of innate immune response and molecular pathogenesis. Int. Rev. 694 Immunol. 36(2):89-107.

695 Morimoto, R.I. 1993. Cells in stress: transcriptional activation of heat shock 696 genes. Science, 259 (5100): 1409-10.

Moseley, P.L. 1997. Heat shock proteins and heat adaptation of the whole organism. J Appl. Physiol. 83(5):1413-7. doi: 10.1152/jappl.1997.83.5.1413.

Motta, V., Soares, F., Sun, T., and Philpott, D.J. 2015. NOD-like receptors: versatile cytosolic sentinels. Physiol. Rev. 95 (1): 149 -178. doi:10.1152/physrev.00009.2014.

Muller-Doblies, D., Ackermann, M. and Metzler, A. 2002. In vitro and in vivo detection of Mx gene products in bovine cells following stimulation with alpha/beta interferon and viruses. Clinical and Diagnostic Laboratory Immunology, 9(6):1192-1199.

Nakatsu, Y., Yamada, K., Ueda, J., Onogi, A., et al. 2004. Genetic polymorphisms and antiviral activity in the bovine MX1 gene. Animal Genetics, 35(3):182-187.

Nayeri, S., Sargolzaei, M., Abo-Ismail, M., Miller, S., Schenkel, F., Moore, S., and Stothard, P. 2017. Genome-wide association study for lactation persistency, female fertility, longevity, and lifetime profit index traits in Holstein dairy cattle. Journal of Dairy Science, 100 (2):1246-58.

Nguyen, T.T., Bowman, P.J., Haile-Mariam, M., Pryce, J.E., and Hayes, B.J. 2016. Genomic

Osei-Amponsah, R., Chauhan, S.S., Leury, B.J., Cheng, L., Cullen, B., Clarke, I.J., and 9(11):948. https://doi.org/10.3390/ani9110948. 
716 Oshiumi, H., Matsumoto, M., Funami, K., Akazawa, T., and Seya, T. 2003. TICAM-1, an adaptor molecule that participates in Toll-like receptor 3-mediated interferon-beta induction. Nat. Immunol. 4 (2): 161-167. doi:10.1038/ni886.

Page, T.J., Sikder, D., Yang, L., Pluta, L., Wolfinger, R.D., Kodadek, T., and Thomas, R.S. 2006. Genome-wide analysis of human HSF1 signaling reveals a transcriptional program linked to cellular adaptation and survival. Mol. Biosyst. 2(12):627-39.

Panaretou, B., Siligardi, G., Meyer, P., Maloney, A., et al. 2002. Activation of the ATPase activity of hsp90 by the stress-regulated cochaperone aha1. Mol. Cell 10(6):1307-18. doi: 10.1016/s1097-2765(02)00785-2.

Pant, S.D., Schenkel, F.S., Leyva-Baca, I., Sharma, B.S. and Karrow, N.A. 2007. Identification of single nucleotide polymorphisms in bovine CARD15 and their associations with health and production traits in Canadian Holsteins. BMC Genomics, 8: 421.

Paula-Lopes, F., Lima, R., Satrapa, R., and Barros, C. 2013. Physiology and endocrinology symposium: influence of cattle genotype (vs.) on oocyte and preimplantation embryo resistance to increased temperature. Journal of Animal Science, 91(3):1143-1153.

731

732

733

734

735

736

737

738

739

Pawar, H.N., Kumar, G.R., Narang, R., Agrawal., K.R. 2014. Heat and cold stress enhances the expression of heat shock protein 70 , heat shock transcription factor 1 and cytokines (IL-12, TNF- and GMCSF) in buffaloes. Int. J. Curr. Microbiol. App. Sci. 3(2):307-317.

Perelygin, A.A., Lear, T.L., Zharkikh, A.A. and Brinton, M.A. 2005. Structure of equine 2'-5' oligoadenylate synthetase (OAS) gene family and FISH mapping of OAS genes to ECA8p15 -> p14 and BTA17q24 -> q25. Cytogenetic and Genome Research, 111 (1): 5156.

Perelygin, A.A., Zharkikh, A.A., Scherbik, S.V., and Brinton, M.A. 2006a. The mammalian 2'-5' oligoadenylate synthetase gene family: Evidence for concerted evolution of 
paralogous Oas1 genes in Rodentia and Artiodactyla. The Journal of Molecular Evolution, 63(4): $562-576$.

Pina-Vazquez, C., De Nova-Ocampo, M., Guzman-Leon, S., and Padilla-Noriega, L. 2007. Post translational regulation of rotavirus protein NSP1 expression in mammalian cells. Archives in Virology, 152(2):345-368.

Pirkkala, L., Nykänen, P., and Sistonen, L. 2001. Roles of the heat shock transcription factors in regulation of the heat shock response and beyond. FASEB J. 15:1118-1131.

Qiu, X.B., Shao, Y.M., Miao, S., and Wang, L. 2006. The diversity of the DnaJ/Hsp40 family, the crucial partners for Hsp70 chaperones. Cell Mol. Life Sci. 63(22):2560-70. doi: 10.1007/s00018-006-6192-6.

Rosenkrans, C.J., Banks, A., Reiter, S., and Looper, M. 2010. Calving traits of crossbred 751 Brahman cows are associated with Heat Shock Protein 70 genetic polymorphisms. Anim. Reprod. Sci. 119(3-4):178-182.

Ryan, A.M., and Womack, J.W. 1993. Hybridization profiles and restriction fragment length polymorphisms for bovine and ovine interferon genes. Animal Biotechnology, 4(1): 11-

Ryan, A.M., Hutcheson, D.P. and Womack, J.E. 1993. Type-I interferon genotypes and severity of clinical-disease in cattle inoculated with bovine herpesvirus-1. American Journal of Veterinary Research, 54(1):73-79.

Sadler, A.J. and Williams, B.R.G. 2008. Interferon-inducible antiviral effectors. Nature Reviews Immunology, 8(7):559-568.

Salces-Ortiz, J., Gonzalez, C., Moreno. S.N., et al. 2013. Ovine HSP90AA1 expression rate is affected by several SNPs at the promoter under both basal and heat stress conditions. PLoS ONE, 8(6): e66641. 
764 Seth, R.B., Sun, L., Ea, C.K., and Chen, Z.J. 2005. Identification and characterization of MAVS, a mitochondrial antiviral signaling protein that activates NF-kappaB and IRF 3. Cell, 122 (5): 669 - 682. doi:10.1016/j.cell.2005.08.012.

Shaji, S., Sejian, V., Bagath, M., Mech, A., David, C.G., Kurien, E.K., Varma, G., and Bhatta, R. 2015. Adaptive capability as indicated by behavioral and physiological responses, plasma HSP70 level, and PBMC HSP70 expression in Osmanabadi goats subjected to combine (heat and nutritional) stressors. Int. J. Biometeorol. 60(4):1311-1323.

Shoemaker, M.L., Smirnova, N.P., Bielefeldt-Ohmann, H., Austin, K.J., van Olphen, A., Clapper, J.A., and Hansen, T.R. 2009. Differential expression of the type I interferon pathway during persistent and transient bovine viral diarrhea virus infection. Journal of Interferon and Cytokine Research, 29(1):23-35.

Singh, U., Deb, R., Alyethodi, R.R., Alex, R., Kumar, S., Chakraborty, S., Dhama, K., and Sharma, A. 2014. Molecular markers and their applications in cattle genetic research: A review. BGM. 6(2): 49-58. https://doi.org/10.1016/j.bgm.2014.03.001

Sturm, R.A. 2009. Molecular genetics of human pigmentation diversity. Human Molecular Genetics, 18(R1): R9-17.

Sunil, K., Kumar, A., and Kataria, M. 2011. Effect of heat stress in tropical livestock and different strategies for its amelioration. Journal of Stress Physiology \& Biochemistry, 7 (1):45-54.

Takeuchi, O., and Akira, S. 2009. Innate immunity to virus infection. Immunol. Rev. 227:7586.

Takeuchi, O., and Akira, S. 2010. Pattern recognition receptors and inflammation. Cell, 140(6):805-820. doi:10.1016/j.cell.2010.01.022 
787

788

789

790

791

792

793

794

795

796

797

798

799

800

801

802

803

804

805

806

807

808

809

810

811

Taye, M., Kim, J., Yoon, S.H. et al. 2017a. Whole genome scan reveals the genetic signature of African Ankole cattle breed and potential for higher quality beef. BMC Genetics, 18(1):11.

Taye, M., Lee, W., Caetano-Anolles, K., Dessie, T., Hanotte, O., Mwai, O.A., Kemp, S., Cho, S., Oh, S.J., and Lee, H.K. 2017b. Whole genome detection of signature of positive selection in African cattle reveals selection for thermo-tolerance. Animal Science Journal, 88(12):1889-901.

Trinklein, N. D., Murray, J. I., Hartman, S. J., Botsein, D., and Myers, R. M. 2004. The role of heat shock transcription factor 1 in the genome-wide regulation of the mammalian heat shock response. Mol. Biol. Cell, 15 (3):1254-1261. DOI: 10.1091/mbc.e03-10-0738.

Vijayakumar, P., Singaravadivelan, A., Silambarasan P et al. 2019a. Production and Reproduction Performances of Crossbred Jersey Cows. Veterinary Research International, 07(02): 56-59.

Vijayakumar, P., Bakyaraj, S., Singaravadivelan, A., Vasanthakumar, T., and Suresh, R. 2019b. Meta-analysis of mammary RNA seq datasets reveals the molecular understanding of bovine lactation biology. Genome, 62(7):489-501. doi: 10.1139/gen-2018-0144.

Vlasova, A.N., and Saif, L.J. 2021. Bovine Immunology: Implications for Dairy Cattle. Front. Immunol. 12:643206. doi: 10.3389/fimmu.2021.643206

West, A.P., Koblansky, A.A., and Ghosh, S. 2006. Recognition and signaling by toll-like receptors. Annu. Rev. Cell Dev. Biol. 22:409-37; PMID:16822173.

Wilke, K., Martin, A., Terstegen, L., and Biel, S. 2007. A short history of sweat gland biology. International Journal of Cosmetic Science, 29(3):169-179.

Xia, J., Benner, M.J., and Hancock, R.E.W. 2014. NetworkAnalyst - integrative approaches for protein-protein interaction network analysis and visual exploration. Nucleic Acids Res. 42 (W1): W167-W174. 
$812 \mathrm{Xu}, \mathrm{M} ., \mathrm{Liu}$, P.P., and Li, H. 2019. Innate Immune Signaling and Its Role in Metabolic and 813 Cardiovascular Diseases. Physiol. Rev. 99(1):893-948. doi:10.1152/physrev.00065.2017

814 Yamamoto, M., Sato, S., Hemmi, H., Sanjo, H., Uematsu, S., et al. 2002. Essential role for 815 TIRAP in activation of the signalling cascade shared by TLR2 and TLR4. Nature, $\mathbf{4 2 0}$ 816 (6913): 324 -329. doi:10. 1038/nature01182.

817 Yoneyama, M., Kikuchi, M., Natsukawa, T., Shinobu, N., et al. 2004. The RNA helicase RIG-I 818 has an essential function in double-stranded RNA-induced innate antiviral responses. Nat. 819 Immunol. 5 (7): 730 -737. doi:10.1038/ ni1087

820 Yu, J., Bao, E., Yan, J., and Lei, L. 2008. Expression and localization of Hsps in the heart 821 andblood vessel of heat stressed broilers. Cell Stress Chaperones, 13(3):327-335.

822 Zhang, F., Qu, K., Chen, N., Hanif, Q., Jia, Y., Huang, Y., Dang, R., Zhang, J., Lan, X., Chen, 823 H., Huang, B., and Lei, C. 2019. Genome-Wide SNPs and InDels Characteristics of Three 824 Chinese Cattle Breeds. Animals, 9(9):596.

825 Zouboulis, C.C. 2004. Acne and sebaceous gland function. Clinics in Dermatology 22(5):360826 6. doi: $10.1016 /$ j.clindermatol.2004.03.004.

827

828

829

830

831 
832 Table 1. Details of the whole genome dataset are included in the study.

\begin{tabular}{|c|c|c|c|c|c|c|}
\hline $\begin{array}{l}\text { S. } \\
\text { No }\end{array}$ & $\begin{array}{l}\text { Project } \\
\text { accession }\end{array}$ & Run accession & Description & Submitted by & URL & Reference \\
\hline \multirow[t]{6}{*}{1} & PRJNA496267 & SRR8156151 & Sahiwal & Big Data Center & https://www.ncbi.nlm.nih.gov/sra/?term=SRR8156151 & $\begin{array}{l}\text { Iqbal et al. } \\
2019\end{array}$ \\
\hline & & SRR8156141 & Sahiwal & Big Data Center & https://www.ncbi.nlm.nih.gov/sra/?term=SRR8156141 & \\
\hline & & SRR8156150 & Red Sindhi & Big Data Center & https://www.ncbi.nlm.nih.gov/sra/?term=SRR8156150 & \\
\hline & & SRR8156142 & Tharparkar & Big Data Center & https://www.ncbi.nlm.nih.gov/sra/?term=SRR8156142 & \\
\hline & & SRR8156149 & Tharparkar & Big Data Center & https://www.ncbi.nlm.nih.gov/sra/?term=SRR8156149 & \\
\hline & & SRR8156146 & Hariana & Big Data Center & https://www.ncbi.nlm.nih.gov/sra/?term=SRR8156146 & \\
\hline \multirow[t]{2}{*}{2} & PRJNA493191 & SRR8053288 & Kangayam & $\begin{array}{l}\text { AgriGenome } \\
\text { Labs Pvt. Ltd., } \\
\text { Kerala, India }\end{array}$ & https://www.ncbi.nlm.nih.gov/sra/?term=SRR8053288 & - \\
\hline & & SRR8053289 & Tharparkar & $\begin{array}{l}\text { AgriGenome } \\
\text { Labs Pvt. Ltd., } \\
\text { Kerala, India }\end{array}$ & https://www.ncbi.nlm.nih.gov/sra/?term=SRR8053289 & \\
\hline
\end{tabular}


837 Table 2. The number of variants identified in different Bos indicus cattle breeds.

\begin{tabular}{|r|l|r|r|r|r|r|r|}
\hline $\begin{array}{l}\text { S. } \\
\text { No }\end{array}$ & $\begin{array}{l}\text { Type of } \\
\text { variants }\end{array}$ & Kangayam & Tharparkar & Sahiwal & \multicolumn{1}{l|l}{$\begin{array}{l}\text { Red } \\
\text { Sindhi }\end{array}$} & $\begin{array}{l}\text { Tharparkar } \\
\text { Pakistan }\end{array}$ & \multicolumn{1}{l|}{ Hariana } \\
\hline 1 & SNP & $1,95,40,715$ & $1,84,47,104$ & $3,02,72,761$ & $1,77,67,764$ & $3,36,33,054$ & $2,12,02,095$ \\
\hline 2 & MNP & $19,51,318$ & $15,88,122$ & $13,72,995$ & $10,97,380$ & $16,24,353$ & $8,20,756$ \\
\hline 3 & INS & $8,49,551$ & $7,99,245$ & $6,99,406$ & $5,89,231$ & $8,72,434$ & $6,20,425$ \\
\hline 4 & DEL & $9,00,655$ & $8,24,621$ & $6,84,992$ & $6,84,044$ & $8,81,898$ & $6,18,835$ \\
\hline 5 & MIXED & $4,51,688$ & $4,91,832$ & $2,12,097$ & $1,95,019$ & $2,79,742$ & $1,52,790$ \\
\hline & Total & $\mathbf{2 , 3 6 , 9 3 , 9 2 7}$ & $\mathbf{2 , 2 1 , 5 0 , 9 2 4}$ & $\mathbf{3 , 3 2 , 4 2 , 2 5 1}$ & $\mathbf{2 , 0 3 , 3 3 , 4 3 8}$ & $\mathbf{3 , 7 2 , 9 1 , 4 8 1}$ & $\mathbf{2 , 3 4 , 1 4 , 9 0 1}$ \\
\hline
\end{tabular}

840

841

842 
843 Table 3. The number of effects by impact identified in different Bos indicus cattle breeds.

\begin{tabular}{|r|l|r|r|r|r|r|r|}
\hline $\begin{array}{l}\text { S. } \\
\text { No }\end{array}$ & $\begin{array}{l}\text { Type of } \\
\text { variants }\end{array}$ & Kangayam & Tharparkar & Sahiwal & $\begin{array}{l}\text { Red } \\
\text { Sindhi }\end{array}$ & $\begin{array}{l}\text { Tharparkar } \\
\text { Pakistan }\end{array}$ & Hariana \\
\hline 1 & HIGH & 17,078 & 23,017 & 51,104 & 8,700 & 31,282 & 18,013 \\
\hline 2 & LOW & $3,03,074$ & $3,07,052$ & $18,62,740$ & $3,05,130$ & $5,22,767$ & $3,96,765$ \\
\hline 3 & MODERATE & $1,83,068$ & $1,83,087$ & $12,65,155$ & $1,61,896$ & $6,06,921$ & $4,24,566$ \\
\hline 4 & MODIFIER & $9,46,39,357$ & $9,06,99,322$ & $15,49,96,738$ & $8,62,15,209$ & $9,38,13,969$ & $6,04,77,873$ \\
\hline 5 & Ts/Tv ratio & 2.166 & 2.1931 & 2.1662 & 2.2634 & 2.24 & 2.1901 \\
\hline
\end{tabular}

844

845

846

847

848

849

850

851

852

853

854 
Table 4. The number of effects by type in different Bos indicus cattle breeds.

\begin{tabular}{|c|c|c|c|c|c|c|c|}
\hline S.No & Type of variants & Kangayam & Tharparkar & Sahiwal & $\begin{array}{l}\text { Red } \\
\text { Sindhi } \\
\end{array}$ & $\begin{array}{l}\text { Tharparkar_ } \\
\text { Pakistan }\end{array}$ & Hariana \\
\hline 1 & 3_prime_UTR_variant & $3,96,922$ & $3,85,074$ & $11,16,812$ & $3,78,124$ & $7,88,568$ & $5,77,996$ \\
\hline 2 & 5_prime_UTR_premature_start_codon_gain_variant & 12,622 & 13,230 & 29,891 & 13,452 & 22,908 & 16,657 \\
\hline 3 & 5_prime_UTR_variant & 91,253 & 97,645 & $3,12,672$ & 99,839 & $2,00,295$ & $1,50,644$ \\
\hline 4 & Conservative_inframe_deletion & 754 & 776 & 695 & 662 & 604 & 367 \\
\hline 5 & Conservative_inframe_insertion & 1,529 & 2,777 & 678 & 469 & 533 & 337 \\
\hline 6 & Disruptive_inframe_deletion & 502 & 579 & 549 & 377 & 329 & 222 \\
\hline 7 & Disruptive_inframe_insertion & 836 & 1,388 & 442 & 232 & 307 & 216 \\
\hline 8 & Downstream_gene_variant & $52,72,628$ & $50,99,841$ & $97,81,382$ & $50,22,053$ & $51,88,496$ & $34,55,491$ \\
\hline 9 & Frameshift_variant & 8,056 & 12,925 & 3,652 & 2,863 & 2,853 & 1,972 \\
\hline 10 & Gene_fusion & 20 & 270 & 0 & 0 & 0 & 0 \\
\hline 11 & Initiator_codon_variant & 30 & 37 & 411 & 33 & 238 & 157 \\
\hline 12 & Intergenic_region & $1,47,22,123$ & $1,35,51,397$ & $1,84,58,394$ & $1,21,35,884$ & $2,10,34,988$ & $1,29,02,426$ \\
\hline 13 & Intragenic_variant & $7,89,552$ & $7,55,667$ & $12,09,242$ & $7,13,634$ & $3,37,797$ & $2,09,957$ \\
\hline 14 & Intron_variant & $3,42,25,372$ & $3,29,94,472$ & $5,59,39,360$ & $3,15,28,499$ & $6,09,69,728$ & $3,96,85,948$ \\
\hline 15 & Missense_variant & $1,83,959$ & $1,86,543$ & $12,64,066$ & $1,60,785$ & $6,05,986$ & $4,23,836$ \\
\hline 16 & Non_coding_transcript_exon_variant & $1,84,061$ & $1,81,420$ & $4,34,306$ & $1,78,583$ & $2,77,263$ & $2,01,288$ \\
\hline 17 & Non_coding_transcript_variant & $3,38,45,164$ & $3,26,89,713$ & $5,84,19,394$ & $3,12,53,278$ & 324 & 220 \\
\hline 18 & Splice_acceptor_variant & 2,703 & 2,772 & 11,056 & 2,150 & 7,497 & 3,742 \\
\hline 19 & Splice_donor_variant & 2,119 & 2,562 & 16,799 & 1,451 & 6,655 & 5,989 \\
\hline 20 & Splice_region_variant & 61,035 & 62,285 & $2,85,941$ & 57,579 & $1,38,723$ & 91,239 \\
\hline 21 & Start_lost & 390 & 381 & 1,867 & 338 & 766 & 638 \\
\hline 22 & Stop_gained & 4,873 & 6,909 & 15,614 & 1,812 & 11,925 & 4,849 \\
\hline 23 & Stop_lost & 391 & 376 & 2,564 & 326 & 1,933 & 1,019 \\
\hline 24 & Stop_retained_variant & 158 & 193 & 721 & 157 & 316 & 253 \\
\hline 25 & Synonymous_variant & $2,40,578$ & $2,43,219$ & $16,10,092$ & $2,43,662$ & $3,91,382$ & $3,07,235$ \\
\hline 26 & Upstream_gene_variant & $51,65,082$ & $49,98,275$ & $95,69,089$ & $49,54,954$ & $51,34,209$ & $33,73,050$ \\
\hline
\end{tabular}




\section{$858 \quad$ Figure Legends}

860 Fig. 1. KEGG pathway analysis of genes comprising of high and moderate impact.

861

862 Fig. 2. A protein-protein interaction network was constructed based on candidate genes involved in the disease resistance mechanism.

864 Fig. 3. A protein-protein interaction network was constructed based on candidate genes involved in the thermotolerance mechanism. 


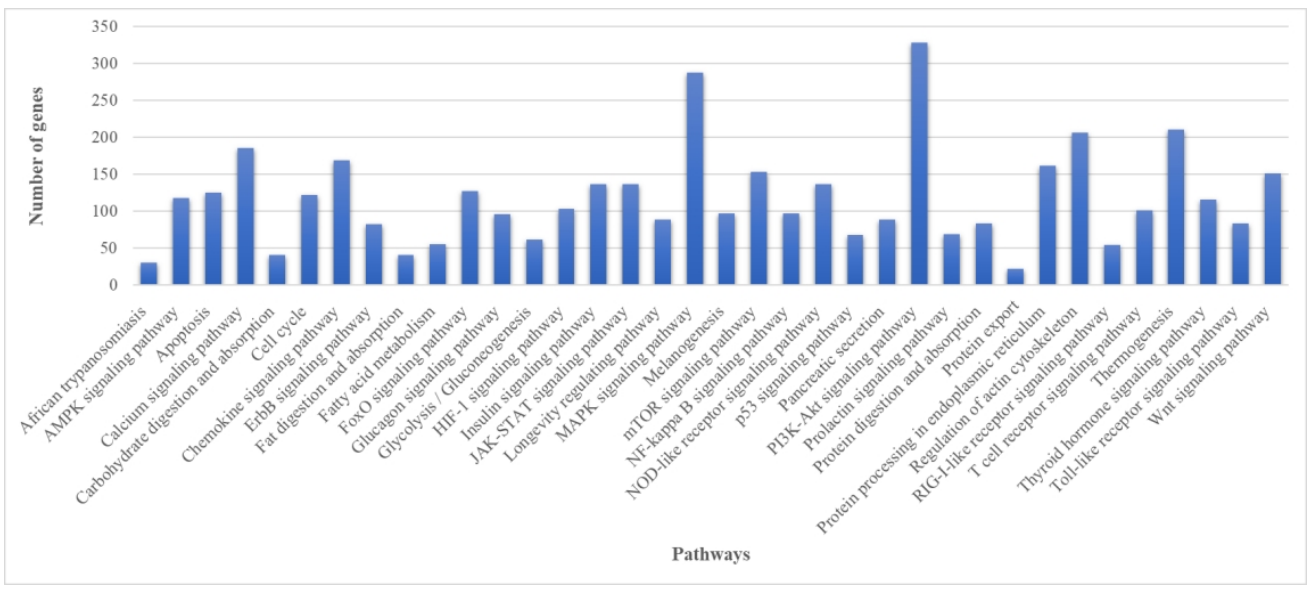




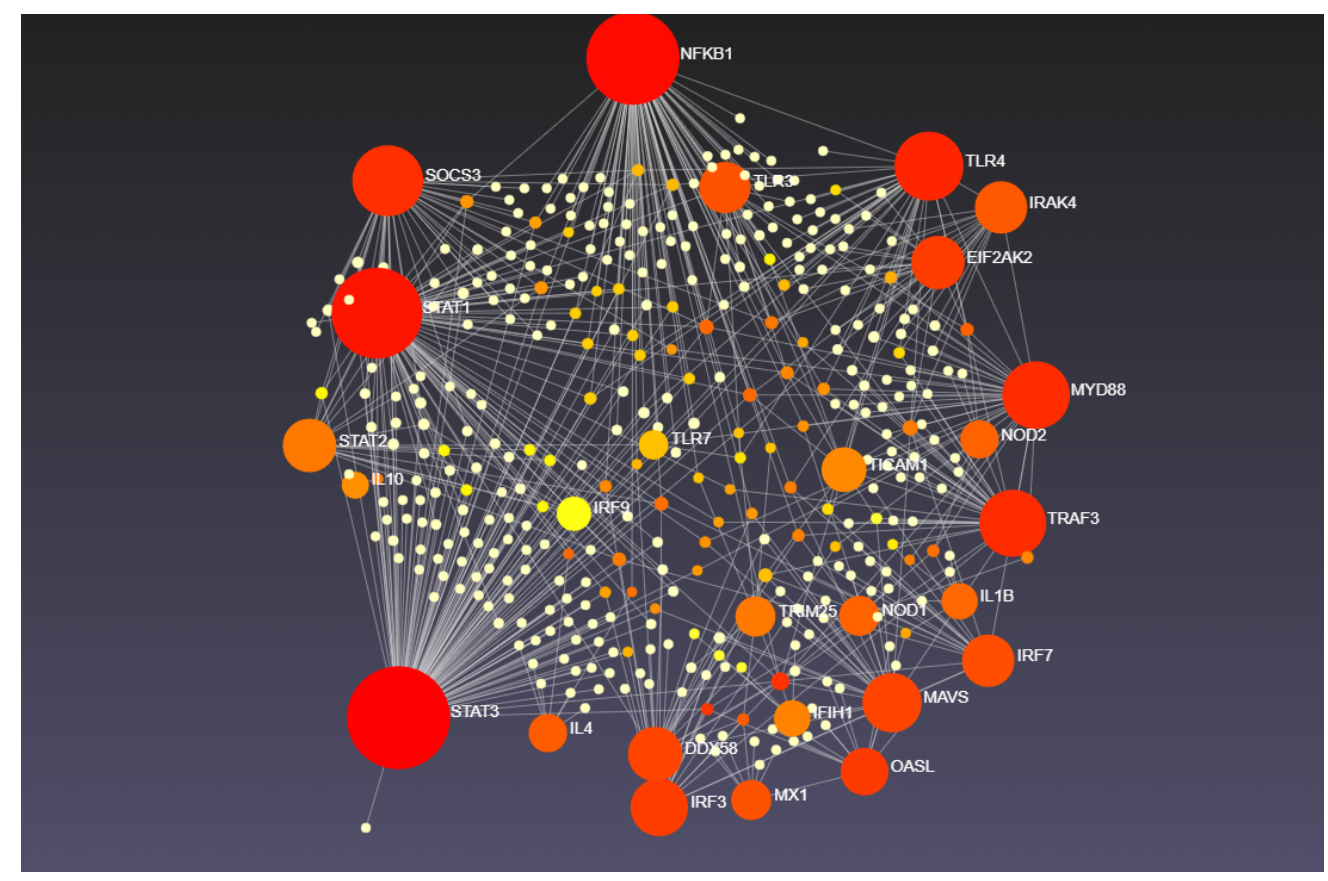

(c) The Author(s) or their Institution(s) 


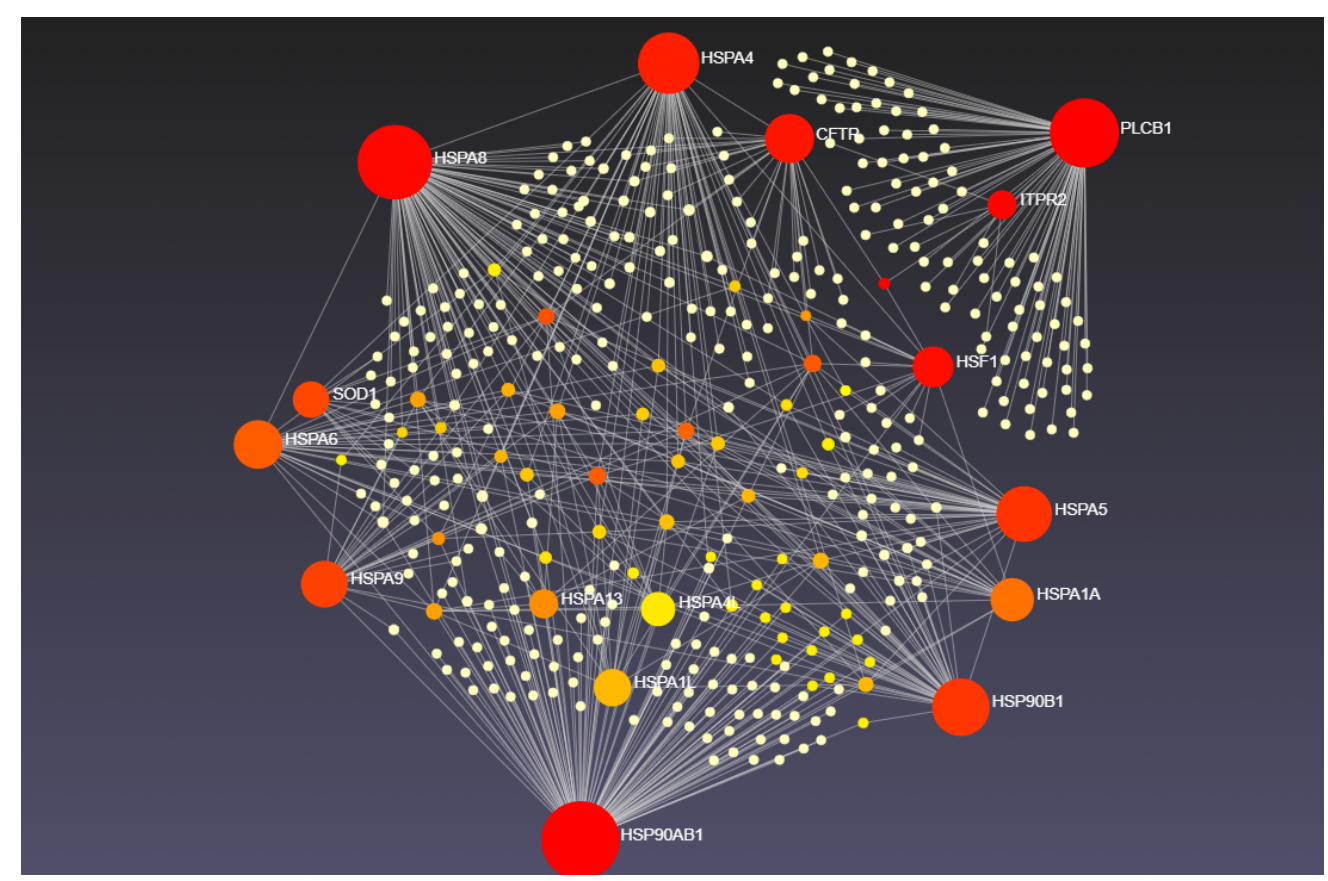

